Jurnal Ogrotech 10 (2) 60-65, Desember 2020

e-ISSN : 2621-7236

p-ISSN : 1858-134X

\title{
SELEKSI DAN EVALUASI PERUBAHAN WARNA HASIL PERSILANGAN JAGUNG UNGU DAN JAGUNG KUNING MANIS PADA GENERASI F2, F3 DAN F4
}

\section{SELECTION AND EVALUATION OF COLOR CHANGES FROM CROSSING OF PURPLE AND SWEET CORN IN GENERATIONS F2, F3 AND F4}

\author{
Mustakim $^{1}$, Maemunah ${ }^{1 *}$, Sakka Samudin ${ }^{1}$, Yusran $^{2}$ \\ ${ }^{1)}$ Program Studi Agroteknologi, Fakultas Pertanian, Universitas Tadulako, Palu \\ ${ }^{2)}$ PLP Fakultas Pertanian Universitas Tadulako \\ Jln. Soekarno Hatta Km. 9 Palu 94118 Sulawesi Tengah Indonesia
}

\begin{abstract}
ABSTRAK
Penelitian ini bertujuan untuk mengevaluasi persentase perubahan warna karnel hingga generasi F4 dan kemajuan seleksi pada generasi F4. Penelitian dilaksanakan pada bulan Agustus 2017 sampai Agustus 2020 di desa Kalukubula, Kabupaten Sigi, Palu, Provinsi Sulawesi Tengah. Penelitian ini disusun menggunakan Rancangan Acak Kelompok dengan lima perlakuan warna karnel yang di ulang sebanyak lima kali. Penelitian ini menggunakan metode seleksi massa dengan memilih warna karnel sesuai perlakuan (ungu, kuning, putih, ungu dominan kuning dan putih dominan ungu). Setiap perlakuan ditanam disatu petakan pada setiap generasi. Benih ditanam menggunakan isolasi waktu yaitu 21 HST. Hasil penelitian menunjukkan bahwa terdapat tiga karakter warna karnel yang mengalami peningkatan persentase warna hingga ke generasi F4 yaitu karnel Ungu (27.68\%-70.39\%), Putih Dominan Ungu (1.52\%-16.91\%) dan Putih (5.40\%-91.22\%), serta terdapat dua karakter warna karnel yang mengalami penurunan persentase warna pada generasi F4 yaitu karnel warna Kuning (68.14\%-64.31\%) dan Ungu Dominan Kuning (27.00\%-5.22\%). Karakter warna karnel Ungu, Putih Dominan Ungu dan Putih mengalami peningkatan nilai heritabilitas yang signifikan pada populasi $\mathrm{F} 4$, serta memiliki nilai kemajuan genetik harapan $(36.94 \%, 17.56 \%, 53.55 \%)$ dan kemajuan seleksi yang positif pada generasi F4.
\end{abstract}

Katakunci: evaluasi, hasil persilangan dan kemajuan seleksi

\section{ABSTRACT}

This study aims to evaluate the percentage change in carnelian color up to the F4 generation and the selection progress in the F4 generation. The research was conducted from August 2017 to August 2020 in Kalukubula village, Sigi Regency, Palu, Central Sulawesi Province. This study was structured using a randomized block design with five carnelian color treatments that were repeated five times. This study used a mass selection method by selecting the carnel color according to the treatment (purple, yellow, white, purple dominant yellow and white dominant purple). Each treatment was planted in one plot for each generation. The seeds were planted using an isolation time of 21 DAS. The results showed that there were three color carnelian characters that experienced an increase in the percentage of color up to the F4 generation, namely Purple (27.68\% -70.39\%), White Dominant Purple (1.52\%-16.91\%) and White (5.40\%-91.22\%), and There are two carnelian color characters that experience a decrease in the percentage of color in the F4 generation, namely Yellow (68.14\% -64.31\%) and Purple Dominant Yellow (27.00\%-5.22\%). The character of purple, white, dominant purple and white carnelian color had a significant increase in heritability values in the F4 population, and had an expected genetic progression value $(36.94 \%, 17.56 \%, 53.55 \%)$ and positive selection progress in the F4 generation.

Keywords: evaluation, crosses result and selection progress

\footnotetext{
${ }^{*}$ Penulis Korespondensi.

E-mail: maemunah.tadulako2@gmail.com

Telp: +62-81355501143
} 


\section{Pendahuluan}

Jagung merupakan bahan pangan utama masyarakat Indonesia setelah beras dan sagu dan terdapat beberapa jenis jagung yang di konsumsi dan diolah, seperti jagung manis, karnel kuning), dan jagung ungu (karnel ungu). Jagung manis (karnel kuning) memilki keunggulan rasa manis yang diakibatkan oleh tingginya kandungan karbohidrat dalam biji. Jagung ungu (karnel ungu) memilki kandungan kadar antosianin yang tinggi dan baik untuk kesehatan, (Mustakim et al., 2020).

Kombinasi persilangan yang dilakukan pada kedua jagung tersebut bermanfaat bagi program pemuliaan (breeding) tanaman jagung terutama jika diarahkan untuk mendapatkan karakter warna yang bervariasi dengan memiliki kombinasi sifat kadar antosianin dan rasa yang manis, (Maulidha dan Sugiharto, 2019).

Seleksi dan pemurnian hasil persilangan sangat dibutuh dalam program pemuliaan. Seleksi bermanfaat untuk mendapatkan karakter yang diinginkan sedangkan pemurnian bermanfaat untuk menyeragamkan karakter yang diinginkan. Dalam penelitian ini seleksi bermanfaat untuk mendapatkan karakter warna karnel yang bervariasi setelah persilangan, sedangkan pemurnian bermanfaat untuk mendapatkan keseragaman warna karnel dalam satu tongkol, (Mustakim et al., 2020; Syukur et al., 2015).

Seleksi dan pemurnian hasil persilangan untuk tanaman menyerbuk silangan dapat menggunakan metode seleksi Massa. Seleksi massa merupakan seleksi berdasarkan karakter yang diinginkan (warna karnel) dan ditanam kembali pada generasi lanjut hingga mendapatkan karakter yang diinginkan dengan seragam, (Mustakim et al., 2020).

Penelitian ini bertujuan untuk mengevaluasi persentase perubahan warna karnel hingga generasi F4 dan mengevaluasi kemajuan seleksi pada generasi F4.

\section{Metode Penelitian}

Penelitian ini dilaksanakan pada bulan Agustus 2017 sampai Agustus 2020 di desa Kalukubula, Kabupaten Sigi, Palu, Provinsi Sulawesi Tengah.

Alat yang digunakan ialah kertas label, cangkul, camera, selang dan alat menulis. Bahan yang digunakan ialah benih jagung hasil
p-ISSN : 1858-134X

persilangan dengan karakter warna karnel Ungu, Kuing, Putih, Ungu dominan kuning dan Putih dominan ungu, pupuk kandang, pupuk NKP mutiara (16:16:16) serta insektisida.

Penelitian ini disusun menggunakan Rancangan Acak Kelompok (RAK) dengan 5 perlakuan warna karnel yang di ulang sebanyak 5 kali dan penelitian ini juga menggunakan metode seleksi massa dengan memilih warna karnel sesuai perlakuan (Ungu, Kuning, Putih, Ungu dominan kuning dan Putih dominan ungu) yang tanam disatu petakan dengan satu warna yang sama pada setiap generasinya, serta penanaman benih menggunakan isolasi waktu tanam selama 21 HST untuk mencegah terjadinya penyerbukan silang antar warna yang berbeda.

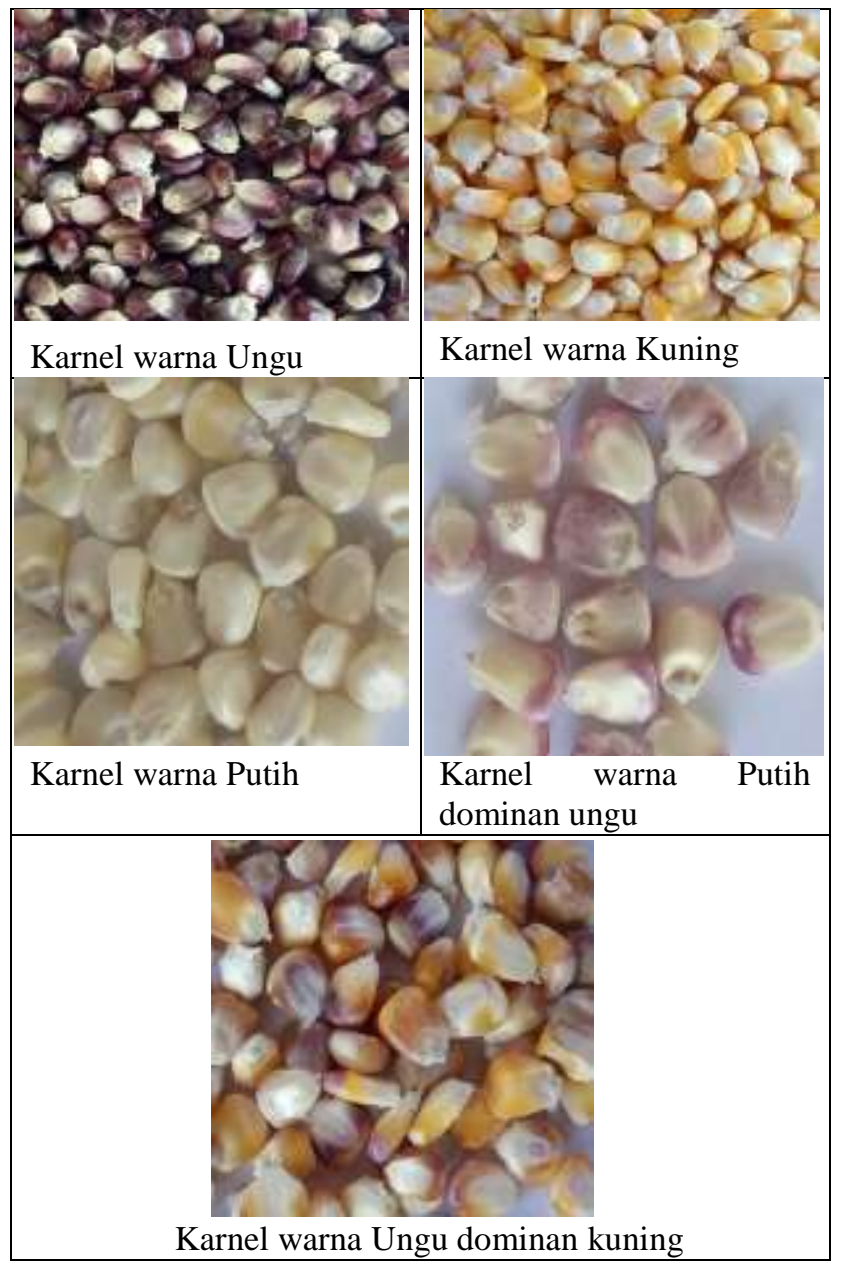

Gambar 1. Karakter warna karnel sebagai perlakuan yang digunakan 
Jurnal Ogrotech 10 (2) 60-65, Desember 2020

Data persentase warna karnel generasi F2, F3 dan $\mathrm{F} 4$ yang dihitung menggunakan rumus,

$$
\frac{\text { Jumlah Warna biji }}{\text { Total Biji Per Tongkol }} \times 100
$$

Koefisien keragaman genetik dihitung menggunakan formulasi (Burton \& DeVane, 1953).

$\mathrm{KKF}=\left(\sqrt{\sigma_{f}^{2}} / \bar{x}\right) \times 100=\sigma_{f}^{2}=K T P / r$

$\mathrm{KKG}=\left(\sqrt{\sigma_{g}^{2}} / \bar{x}\right) \times 100=\sigma_{g}^{2}=K T G-K T G / r$

Dimana : KKG = Koefisien Keragaman Genetik

$\mathrm{KKF}=$ Koefisien Keragaman Fenotip

$\mathrm{r} \quad=$ ulangan

Heritabilitas dengan nilai $0-<30 \%$ tergolong rendah, 30-60\% tergolong sedang dan tinggi >60 (Johnson et al 1955; Mustakim et al., 2019; Syukur et al., 2012).

$\mathbf{h}^{2}=\frac{\sigma_{g}^{2}}{\sigma_{f}^{2}}$

dimana :

\section{Hasil dan Pembahasan}

e-ISSN : 2621-7236

p-ISSN : 1858-134X

$\mathrm{h}^{2}=$ heritabilitas

$\sigma_{g}^{2}=$ ragam genetik

$\sigma_{f}^{2}=$ ragam fenotipik

Kemajuan genetik harapan mengacu pada (Johnson et al., 1955; Yunandra et al., 2017)

$G=(i)\left(\sigma_{p}\right)\left(h_{\mathrm{ns}}^{2}\right)$

dimana :

$$
\begin{aligned}
& \mathrm{G}=\text { Kemajuan Genetik Harapan } \\
& i=\text { Intensitas Seleksi } \\
& \sigma_{p}=\text { Simpangan Baku Fenotipe } \\
& h^{2}{ }_{\mathrm{ns}}=\text { Heritabilitas Arti Sempit }
\end{aligned}
$$

Kemajuan Seleksi mengacu pada (Syukur et al., 2015; Yunandra et al., 2017)

$G=\bar{x} F_{n}-\bar{x} F_{n-1}$

$G=\bar{x} F_{4}-\bar{x} F_{3}$

dimana :

$$
\begin{array}{ll}
\mathrm{G} & =\text { Kemajuan Seleksi } \\
\overline{x F_{3}} & =\text { Nilai Tengah Populasi F3 } \\
\overline{x F_{4}} & =\text { Nilai Tengah Populasi F4 }
\end{array}
$$

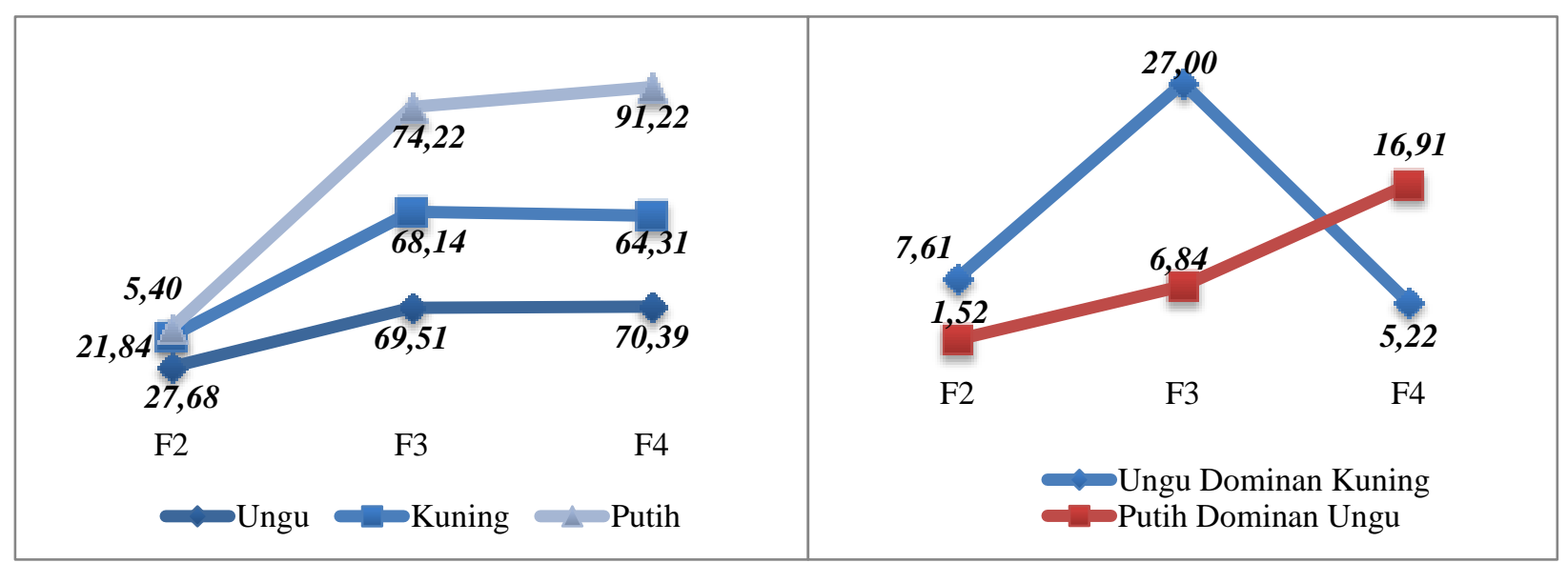

Gambar 2. Persentase Warna pada generasi F2, F3 dan F4.

Karakter warna ungu mengalami peningkatan persentase warna setiap generasi hingga generasi F4 walaupun kenaikan persentase warna dari generasi F3 ke F4 dari tidak signifikan. karakter warna putih dominan ungu dan warna putih mengalami peningkatan persentase warna yang signifikan dari generasi F2 hingga F4. Hasil penelitian (Sutresna, 2010) daya hasil populasi hasil seleksi massa siklus pertama, kedua dan ketiga sama dengan (tidak berbeda nyata) dibanding dengan populasi awal. Karakter warna ungu dominan kuning dan warna kuning mengalami peningkatan persentase warna dari generasi F2 ke F3, akan tetapi pada generasi F4 mengalami penurunan persentase warna. 
Karakter warna ungu merupakan karakter yang diturunkan dari tetua jantan yaitu jagung karnel ungu dan karakter warna kuning merupakan karakter yang diturunkan dari tetua betina yaitu jagung karnel kuning manis, sedangkan karakter warna putih merupakan karakter warna intermediet yang muncul pada generasi F2. Hasil penelitian (Runtunuwu at al., 2019) tingkat kemurnian Tanaman F2 jagung manado kuning karnel putih jangel puit dengan menggunakan metode Ear to Row didapatkan hasil persentase biji putih penuh rata-rata $95,85 \%$ sedangkan karnel yang bercampur putih dan kuning menghasilkan presentase rata-rata $4,15 \%$, persentase warna janggel putih $63.2 \%$, dan hasil persentase karnel merah 36,8\%.

Karakter intermediet ini muncul diakibatkan oleh kedua pasang alel (warna ungu dan kuning) memiliki sifat yang sama kuat sehingga alel yang muncul berbeda dengan alel kedua tetuanya. Ketiga karakter ini menjadi karakter dominan pada generasi F3 dan F4 sehingga peningkatan persentase warnanya lehih tingga dibanding dua karakter yang lainnya yaitu karakter ungu dominan kuning dan putih dominan ungu.

Karakter ungu dominan kuning dan putih dominan ungu merupakan karakter yang muncul Tabel 1. Koefisien Keragaman Genetik, Heritabilitas, Kemajuan Genetik Haraan, Kemajuan Seleksi

\begin{tabular}{|c|c|c|c|c|c|c|}
\hline \multirow[t]{2}{*}{$\begin{array}{l}\text { Variabel Amatan } \\
\text { (Warna Karnel) }\end{array}$} & \multicolumn{2}{|c|}{$\begin{array}{c}\text { Koefisien } \\
\text { Keragaman } \\
\text { Genetik }\end{array}$} & \multicolumn{2}{|c|}{ Heritabilitas } & \multirow{2}{*}{$\begin{array}{c}\text { Kemajuan } \\
\text { Genetik } \\
\text { Haraan }\end{array}$} & \multirow[t]{2}{*}{$\begin{array}{c}\text { Kemajuan } \\
\text { Seleksi }\end{array}$} \\
\hline & F3 & F4 & F3 & F4 & & \\
\hline Ungu & 19.64 & 20.07 & 73.32 & 91.69 & 36.94 & 0.88 \\
\hline Ungu Dominan Kuning & 7.34 & 14.55 & 63.66 & 82.12 & 25.03 & -5.3 \\
\hline Putih Dominan Unggu & 6.40 & 9.61 & 63.21 & 90.65 & 17.56 & 10.06 \\
\hline Kuning & 19.13 & 18.31 & 76.11 & 95.66 & 34.58 & -3.83 \\
\hline Putih & 20.54 & 27.60 & 65.09 & 99.87 & 53.55 & 17.00 \\
\hline $\begin{array}{l}\text { Menurut (Syukure } \\
\text { al. 2019) bahwa nilai } \\
\text { genetik dibagi } 3 \text { golonga } \\
\text { antara } 0-10 \% \text {, tergol } \\
\text { sedangkan tergolong ting } \\
\text { Koefisien keraga } \\
\text { generasi F3 berkisar } \\
20.54 \% \text { sedangkan pada } \\
\text { antara 9.61\% hingga } 2 \\
\text { keragaman genetik } \\
\text { menghasilkan nilai yan } \\
\text { yang memiliki nilai koefi } \\
\text { yang rendah yaitu karak }\end{array}$ & $\begin{array}{l}2011 ; \mathrm{M} \\
\text { fisien } \\
\text { itu rend: } \\
\text { sedang } \\
0 \% \text {. } \\
\quad \text { gene } \\
\text { a } 6.40 \\
\text { nerasi } \mathrm{F} \\
\% \text { Nila } \\
\text { gen } \\
\text { ervariasi } \\
\text { keragam } \\
\text { karnel y }\end{array}$ & $\begin{array}{l}\text { takim } e t \\
\text { agaman } \\
\text { berkisar } \\
\text { 10-20\% } \\
\text { pada } \\
\text { hingga } \\
\text { berkisar } \\
\text { oefisien } \\
\text { si F3 } \\
\text { karakter } \\
\text { genetik } \\
\text { warna }\end{array}$ & $\begin{array}{l}\text { un } \\
\text { do } \\
\text { kar } \\
(19 \\
\text { ker } \\
\text { kar } \\
\text { ger } \\
\text { dir } \\
\text { do } \\
\text { ker } \\
\text { yar } \\
\text { ku }\end{array}$ & $\begin{array}{l}\text { domina } \\
\text { lan Ung } \\
\text { yang be } \\
\% \text { ), sed } \\
\text { aman ge } \\
\text { yang be } \\
\text { Nilai kc } \\
\text { asi F4 ju } \\
\text { a karak } \\
\text { lan un } \\
\text { aman ger } \\
\text { gerwarna } \\
\text { g memi }\end{array}$ & $\begin{array}{l}\text { kuning }(7.3 \\
40 \%) \text {, Sedar } \\
\text { rna ungu (19. } \\
\text { an yang mili } \\
\text { k yang ting. } \\
\text { rna putih ( } 20 . \\
\text { sien keragam } \\
\text { nemiliki nilai } \\
\text { karnel yang } \\
\text { mimiliki } \\
\text { yang rendah } \\
\text { gu dominan k } \\
\text { nilai koefi }\end{array}$ & $\begin{array}{l}\text { dan putih } \\
\text { yaitu karakter } \\
\% \text { ) dan kuning } \\
\text { nilai koefisien } \\
\text { yaitu karakter } \\
\% \text { ). } \\
\text { genetik pada } \\
\text { ang bervariasi, } \\
\text { erwarna putih } \\
\text { lai koefisien } \\
\text { carakter karnel } \\
\text { ing dan karnel } \\
\text { n keragaman }\end{array}$ \\
\hline
\end{tabular}


genetik yang sedang, dan karakter karnel yang berwarna ungu dan putih memiliki nilai koefisien keragaman genetik yang tinggi.

Nilai heritabilitas pada generasi F3 dan F4 semua tergolong tinggi, dimana pada generasi F3 berkisar antara $63.21 \%-76.11 \%$, sedangkan pada generasi F4 berkisar anatar 82.12\%99.87\%. Nilai duga heritabilitas digunakan untuk mengetahui pewarisan sifat, semakin tinggi nilai heritabilitas suatu sifat maka sifat tersebut semakin cepat diturunkan kegenerasi selanjutnya, begitupun sebaliknya semakin rendah nilai heritabilitas suatu sifat maka sifat tersebut semakin lama diturunkan ke generasi selanjutnya.

Tinggi rendahnya nilai heritabilitas dipengaruhi oleh dua faktor yaitu genetik aditif dan lingkungan. Sifat yang memiliki nilai duga heritabilitas yang tinggi lebih dominan dipengaruhi oleh genetik aditif sehingga sifatnya semakin cepat diturunkan kegenerasi selanjutnya. Sifat yang memiliki nilai heritabilitas yang rendah lebih dominan dipengaruhi oleh faktor lingkungan sehingga sifat tersebut semakin lama diturunkan ke generasi selanjutnya.

Nilai duga heritabilitas juga dapat menjadi salah satu acuan dalam proses seleksi. Seleksi akan berjalan efektif jika nilai duga heritabilitas tinggi, hal ini disebabkan karena pada nilai duga heritabilitas tinggi sifat yang tampak dipengeruhi oleh aksi gen aditif sehingga sifat tersebut akan cepat diturunkan. Sebaliknya jika nilai duga heritabilitas rendah maka seleksi akan kurang efektif, hal ini dikarenakan sifat yang tampak bukan dipengaruhi dari aksi gen aditif akan tetapi pengaruh oleh lingkungan tempat tumbuhnya sehingga sifatnya akan sulit diturunkan. Hasil penelitian (Yunandra at al., 2017) bahwa nilai dugaan kemajuan seleksi karakter yang menjadi kriteria seleksi akan sama atau mendekati kemajuan seleksi sebenarnya pada populasi selanjutnya. Kemajuan seleksi karakter tersebut akan lebih baik apabila aksi gen aditif lebih berperan dalam pewarisan dengan nilai heritabilitas tinggi.

Menurut (Belay at al., 2018) Nilai kemajuan genetik harapan dibagi menjadi 3 kelompok: rendah $<10 \%$, sedang $10 \%-20 \%$, dan tinggi $>20 \%$. Hasil penelitian dapat dilihat bahwa semua karakter warna karnel memiliki nilai kemajuan genetik harapan yang tinggi kecuali warna karnel Putih dominan ungu. Kemajuan genetik harapan digunakan untuk melihat dan menduga sejauh mana karakter warna karnel tersebut untuk dapat menstabilkan genetiknya atau menstabilkan warnanya, semakin tinggi nilai kemajuan genetik harapan maka semakin cepat sifat tersebut untuk menstabilkan genetiknya dan begitupun sebaliknya.

Kemajuan genetik harapan sangat erat hubungannya dengan nilai heritabilitas dimana sifat dengan nilai heritabilitas dan kemajuan genetik harapan yang tinggi, artinya sifat tersebut dikendalikan oleh gen aditif dan gen tersebut akan lebih cepat stabil. Menurut (Soomro et al., 2010) nilai heritabilitas dan kemajuan genetik harapan yang tinggi kemungkinan aksi gen aditif yang berperan dalam seleksi sehingga kegiatan seleksi menjadi efektif.

Kemajuan genetik harapan menjadi indikator penentu kemajuan seleksi, karena semakin cepat gen tersebut menstabilkan genetiknya maka seleksi akan berjalan lebih singkat, hal ini dapat dilihat dari hasil penelitian pada karakter karnel warna ungu, putih, dan putih dominan ungu yang memiliki nilai kemajuan genetik harapan tinggi dan kemajuan seleksi yang tinggi dan positif.

Karakter dengan kemajuan seleksi yang positif menunjukkan bahwa karakter tersebut mengalami peningkatan persentase warna karnel pada generasi lanjut, sedangkan kemajuan seleksi yang negetif menunjukkan bahwa karakter warna karnel mengalami penurunan pada generasi lanjut. Karakter warna Ungu, Putih dominan ungu dan Putih merupakan karakter yang memiliki nilai kemajuan seleksi yang positif, yang artinya ketiga karakter tersebut mengalami peningkatan persentasi warna pada generasi F4 dan begitupun sebaliknya.

\section{Kesimpulan}

Hasil penelitian menunjukkan bahwa terdapat tiga karakter warna karnel yang mengalami peningkatan persentase warna yaitu karnel Ungu (27.68\%-70.39\%), Putih Dominan Ungu (1.52\%-16.91\%) dan Putih (5.40\%- 
91.22\%) hingga ke generasi F4, serta terdapat dua karakter warna karnel yang mengalami penurunan persentase warna pada generasi $\mathrm{F} 4$ yaitu karnel warna Kuning (68.14\%-64.31\%) dan Ungu Dominan Kuning (27.00\%-5.22\%).

Karakter warna karnel Ungu, Putih Dominan Ungu dan Putih mengalami peningkatan nilai heritabilitas yang signifikan pada populasi $\mathrm{F} 4$, serta memiliki nilai kemajuan genetik harapan $(36.94 \%, 17.56 \%, 53.55 \%)$ dan kemajuan seleksi yang positif pada generasi F4.

\section{Daftar Pustaka}

Achmad, A., 2019. Seleksi Satu Tongkol Satu Baris (Ear to Row Selektion) Pada Tanaman Jagung. Rekayasa, 12(1):18-23.

Belay, N., 2018. Genetic Variability, Heritability, Correlation and Path Coefficient Analysis for Grain Yield and Yield Component In Maize Hybrids. Advances in Crop Science and Technology, 6(5): 1-9.

Burton, G.W., dan DeVane, E.H., 1953. Estimating Heritability In Tall Fescue (Festuca arundinacea) from Replicated Clonal Material 1. Agronomy Journal, 45(10): 478-481.

Dewey, D.R., dan Lu, K.H., 1959. A Correlation and Path-Coefficient Analysis of Components of Crested Wheatgrass Seed Production 1 . Agronomy Journal, 51(9): 515-518.

Johnson, H.W., Robinson, H.F., dan R.E. Comstock, R.E., 1955. Estimates of Genetic and Environmental Variability In Soybeans. J. Agronomy, 47: 314-318.

Maulidha. A.R., dan Sugiharto,A.N., 2019. Pengaruh Kombinasi Persilangan Jagung Terhadap Karakter Kualitatif pada Hibridanya (F1). Jurnal Produksi Tanaman, 7(5): 755-765.

Mustakim, Samudin, S., dan Maemunah, 2019. Genetic diversity, Heritability and
Correlation Between Local Cultivars of Upland Rice. Agroland: The Agricultural Sciences Journal, 6(1): 20-26.

Mustakim, Samudin, S., Maemunah, Jeki, dan Yusran, 2020. Karakter Warna dan Persentase Perubahan Warna Hasil Persilangan Jagung Ungu dan Jagung Kuning Manis pada Generasi F1, F2 Dan F3. J. Agrotekbis, 8(2): 251-256.

Runtunuwu, I.R., Runtunuwu, I.R., dan Wanget, S., 2019. Pemurnian Galur Jagung Manado Kuning Karnel Putih Dengan Metode Ear To Row. Cocos, 2(6)

Soomro, Z.A., Kumbhar, M.B., Larik, A.S., Imran, M., dan Brohi, S.A., 2010. Heritability and Selection Response in Segregating Generations of Upland Cotton. Pakistan J. Agric. Res, 23:25-30.

Sutresna, I.W., 2010. Pengaruh Seleksi Massa Terhadap Kemajuan Genetik Populasi Tanaman Jagung. Agroteksos, 20(3): 12118

Syukur, M., Sujiprihati, S., Yunianti, R., dan Kusumah, D.A., 2011. Pendugaan Ragam Genetik dan Heritabilitas Karakter Komponen Hasil Beberapa Genotipe Cabai. J. Agrivigor, 10:148-156.

Syukur, M., Sujiprihati, S., Yunianti, R., dan Nida, K., 2012. Pendugaan Komponen Ragam, Heritabilitas dan Korelasi Untuk Menentukan Kriteria Seleksi Cabai (Capsicum annuum L.) Populasi F5. Jurnal Hortikultura Indonesia, 1(2): 74.

Syukur, M., Sujiprihati, S., dan Yunianti, R., 2015. Teknik Pemuliaan Tanaman. Edisi Revisi. Penebar Swadaya, Jakarta.

Yunandra, Syukur, M., dan Maharijaya, A., 2017. Seleksi dan Kemajuan Seleksi Karakter Komponen Hasil pada Persilangan Cabai Keriting dan Cabai Besar. Jurnal Agronomi Indonesia, 45(2): 169-174. 